\title{
筑波研究学園都市の形成過程における居住者の生活と意識の変容について ON THE CHANGE OF INHABITANTS' BEHAVIOR AND CONSCIOUSNESS IN TSUKUBA NEW TOWN
}

\author{
土肥博 至*, 福本佳世**, 坂 本 淳 二***, 田中一成**** \\ Hiroshi DOHI, Kayo FUKUMOTO, Junji SAKAMOTO \\ and Kazunari TANAKA
}

\begin{abstract}
This study completes our researches about change of inhabitant's living behavior and consciousness in process of urbanization at Tsukuba new town through 23 years.

Conclusion are as follows:

1)The difference that emerged between PRA and POL till 1986 is going to disappear. 2)The change which be utterly different from inherited trends happened between 1988 and 1995, therefore, Tsukuba New Town is going to entered a new stage of urbanization. 3)Change of living behavior happens suddenly also quickly, on the other hand, Change of inhabitant's consciousness is late and slow. 4)Convenience on daily life and progress of urbanization contributed to a rise of inhabitant's consciousness about stable settlement.
\end{abstract}

Keywords: Tsukuba New Town, Process of urbanization, Living behavior, Inhabitants' consciousness

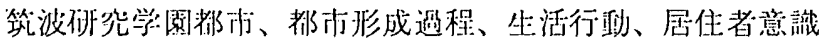

1 ・研究の背景と目的、方法

筑波研究学園都市が、わが国における職住一体の新都市の先駆 けとして建設されはじめてから約30年の月日がすぎようとし、都市 として一定の成熟段階に入ってきていると考えられる。筆者らは、 この新都市における誕生から現在に至るまでの 20 年あまりにわたっ て、継続的に調査を行ってきたが、このような定点観測的、時系列 的研究はわが国では他に類をみない。本論文は、この新都市がたど ってきた経緯を明らかにし、最終的には新都市の都市化に関する一 般的な示唆を得ることを目的に始められた研究の一部である。本研 究の成果はこれまでにも随時発表してきたが、特に土肥、若林が 1988年に発表した本報の中間報告的論文においては1、88年までの 研究学園都市の変容プロセスについていくつかの視点から考察を行 っている。

本報では、都市形成段階における居住者の生活行動及び意識の 変容の実態をいくつかの角度から明らかにすると共に、これら生活 行動と意識の变容にみられる相互関係及び意識と都市空間の物的整 備の諸項目との関係を明らかにすることを目的とする ${ }^{2)} 。$

研究の方法は、これまでに筆者らが実施してきた居住者アンケ 一ト調査の結果を中心に、関連する多くの指標を用いて、分析、考 察を行う。この調査は、1972、75、77、79、80、82、86、88、95年
の9時点において行われた。調査概要については表】に示す通りで ある。

筑波研究学園都市には、計画住宅地と区画整理民有地という性 格の異なる 2 種類の居住地がある。それぞれの居住地は、その建設 方法、建築形態、建設時期等が異なり、またその居住者は、職業構 成、居住形態、入居時期等が異なる。1972年に最初の公務員住宅が 竹園地区に建設され、それ以降1980年までに、8000戸を超える公務 員住宅が計画的に建設された。これらは、公務員住宅以外の計画建 設住宅（公団住宅、公社住宅、公的機関の職貝住宅等）とともに、 いくつかの団地を形成している。そこの居住者を以下＼cjkstart計住〉と略 記する。

一方、区画整理民有地は、1973年から1978年にかけて使用収益が 開始されたが、実際に住宅が建設され始めたのは1980年頃からであ り、その初期の居住者はもともとこの地域に居住していた人たちが 多く、域外からの流入が始まるのは80年代半ばからである。民有地 における住宅は多くの一戸建持ち家を含み、団地は形成せず散在し ている。この地域の居住者を以下＜民地＞と略記する。

<計住 $>$ とく民地〉は、前者が計画的な新都市の側面を表して いるのに対して、後者は都市としての自然的な成長、発展の側面を 表しているといえる。したがって、この都市の実態を把握するため
* 神戸芸術工科大学 教授・工博

** 筑波大学大学院博士課程芸術学研究科 大学院生・ 修士(デザイン学)

*** 筑波大学環境科学研究科 準研究員 - 学修

**** 株式会社宅地開発研究所名古屋支所 研究貣 . 博士(デザイン学)
Prof., Department of Environmental Design, Kobe Design Univ., Dr. Eng.

Graduate Student, Doctoral Program on the Science of Art and Design, Univ. of Tsukuba, M. Design

Research Assoc., Institute of Environmental Sciences, Univ, of Tsukuba M. E. Sciences

Researcher, Takken City Planning Consultants INC., Ph. D. 


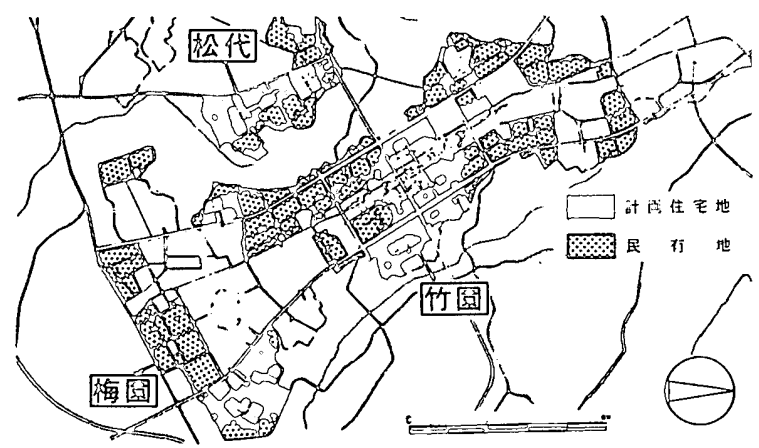

圆 1 調盗対兒地位置圆

には、この両者を別々に調查しなければならない。具体的には、く 計住〉は図 1 に示寸竹图地区居住者、〈民地〉は梅園地区と松代地 区の居住者の一部を調亩対象者とする。

調笽は、それぞれの時点において多項目について行われたもの であり、時系列研究に使用できる項目、すなわち一貫して用いられ た設問は限られたものにならざるを得ない。本研究で居住者の生活 行動と意識を記述、分析するための項目は以下の 4 項目 ${ }^{3)}$ である。 生活行動 意識 購買行動、近啋交流（知人人数） 定住志向、居住環境評価

\section{2.居住者の经活行動について}

\section{(1) 瞍買行動}

戝買行動のうち、購入場所の選択は住民の生活圈をよく表現し、 また新都市内での充足状況は、新都市内での生活面の独立性を端的 に表す指標と考えられる。図2は日用品を代表するものとして生鮮 食㳆品を選び、計住>については、72、75、77、80、86、88、95 の 7 時点、<民地＞については79、82、86、88、95の 5 時点の主な 贈入場所の分布の推移を示したものである。図 3 は同様に、買迴品 の代表として高級衣料品についての年次変化を示す。購入場所とし ては、新都市内 (研究学園地区)、研究学園都市内周辺地域、土 浦・荒川沖、東京・柏の 4 地点に整理し、僅かなその他の場所、無 回答は除外した。

日用品についてみると、まずく計住〉では、最初の調㚗時点に おける居住者の購入地点は新都市内、周辺地域、土浦等に 3 分され ていたが、その㣪1988年まで新都市内の比率が順調に増加する一方、 その他の割合は急激に減少し、88年には土浦等の購入はなくなった。 ただ、1995年の最新のデータでは、新都市内の比率がやや減少し、 その分周辺地域が增えているのが注目される。元々新都市の外縁部 に位置し、周辺地域に近いく民地〉に执いても、1982年以降は新都 市内が $80 \%$ 以上を占めて高い充足状況となった。しかしく民地〉で も1995年には新都市内の比率が低下し、周辺地域の割合が $20 \%$ 超 えている。

このように日用品の購買については、概成 ${ }^{4}$ の 1980 年頃には新都 市内での供給が増大し、居住者が不便を感じる状態ではなくなった といえる。しかし95年調㸖では、<計住〉<民地〉ともに新都市内 が淢り、周辺地域での購買比率が增大している。これは、<民地〉 人口の増加、周边地域での住宅地開発や民間研究所の設立などが背 景となって、周辺地域に大型スーパーや安売店等が建設されだ)こ とが要园と推測される。

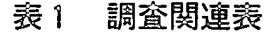

\begin{tabular}{|c|c|c|c|c|c|c|c|c|c|}
\hline \multirow[b]{2}{*}{$\begin{array}{l}\text { 調 } \\
\text { 查 } \\
\text { 洔 } \\
\text { 期 }\end{array}$} & \multirow[b]{2}{*}{$\begin{array}{l}\text { 調 } \\
\text { 育 } \\
\text { 対 } \\
\text { 象 }\end{array}$} & \multirow[b]{2}{*}{$\begin{array}{l}\text { 有 } \\
\text { 効 } \\
\text { 票 } \\
\text { 致 }\end{array}$} & \multirow[b]{2}{*}{$\begin{array}{l}\text { 回 } \\
\text { 収 } \\
\text { 率 }\end{array}$} & \multicolumn{5}{|c|}{ 調蓇項目 } & \multirow[b]{2}{*}{ 出 } \\
\hline & & & & $\begin{array}{c}\text { 旦 } \\
\text { 用 } \\
\text { 品 } \\
\text { 賻 } \\
\text { 買 } \\
\text { 地 } \\
\text { 点 }\end{array}$ & 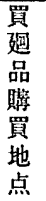 & $\begin{array}{l}\text { 知 } \\
\text { 人 } \\
\text { 人 } \\
\text { 致 }\end{array}$ & $\begin{array}{l}\text { 定 } \\
\text { 住 } \\
\text { 志 } \\
\text { 向 }\end{array}$ & $\begin{array}{l}\text { 居 } \\
\text { 住 } \\
\text { 䶂 } \\
\text { 㜔 } \\
\text { 価 }\end{array}$ & \\
\hline $1972 / 8-9$ & <計住> & 113 & $72.5 \%$ & 0 & $\mathrm{O}$ & & 0 & & 妾 1) \\
\hline $1975 / 11$ & <部住> & 460 & $85.8 \%$ & 0 & 0 & 0 & 0 & 0 & 亲 1) \\
\hline $1977 / 10$ & <計住> & 234 & $91.1 \%$ & 0 & 0 & 0 & 0 & 0 & 妾 1) \\
\hline $1979 / 9$ & <民地 > & 249 & $59.3 \%$ & 0 & 0 & & & 0 & 文 1) \\
\hline $1980 / 10$ & <計住> & 510 & $87.2 \%$ & 0 & 0 & 0 & 0 & 0 & 文 1) \\
\hline $1982 / 5$ & <民地> & 445 & $62.8 \%$ & 0 & $\mathrm{O}$ & 0 & & 0 & 文1） \\
\hline \multirow[t]{2}{*}{$1986 / 10$} & <計住> & 151 & $77.4 \%$ & $\mathrm{O}$ & 0 & 0 & 0 & 0 & 文1） \\
\hline & $<$ 民地 > & 97 & $82.9 \%$ & 0 & 0 & & 0 & 0 & 文 1) \\
\hline \multirow[t]{2}{*}{$1988 / 10$} & <計住> & 327 & $77.8 \%$ & 0 & 0 & 0 & 0 & 0 & 辛 2) \\
\hline & <民地> & 130 & $54.1 \%$ & 0 & 0 & 0 & 0 & 0 & 立 2） \\
\hline \multirow[t]{2}{*}{$1995 / 10$} & <詏住> & 119 & $99.1 \%$ & 0 & 0 & 0 & 0 & 0 & 妾 3) \\
\hline & <民地 > & 184 & $98.3 \%$ & 0 & 0 & 0 & 0 & 0 & 妾 3) \\
\hline
\end{tabular}

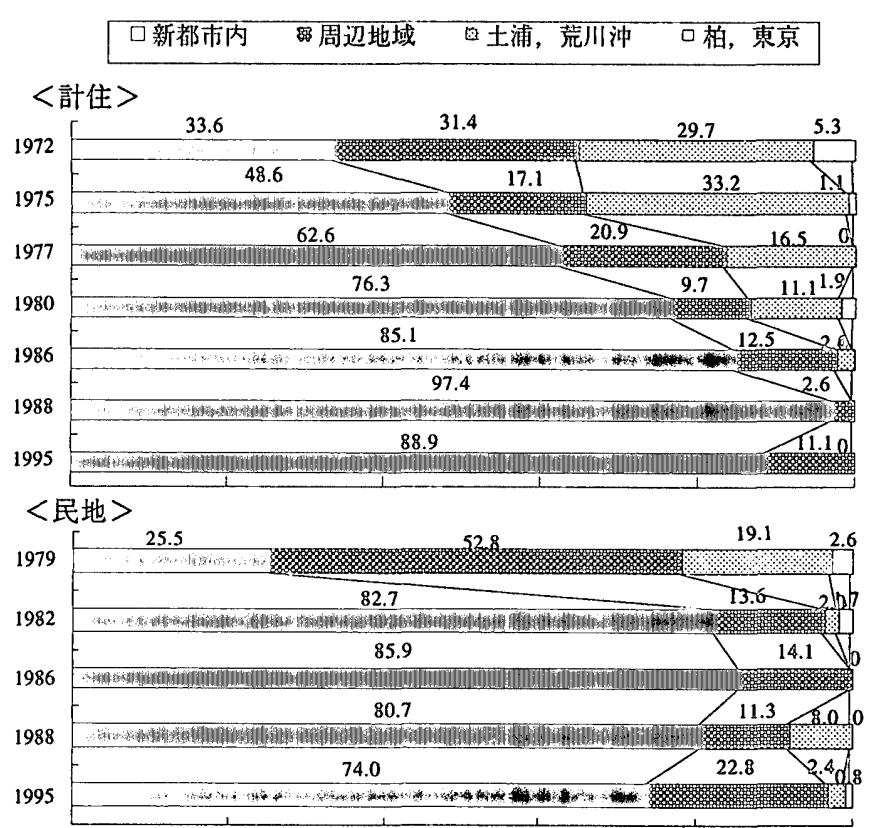

図2日用品䝬入地点灌成比
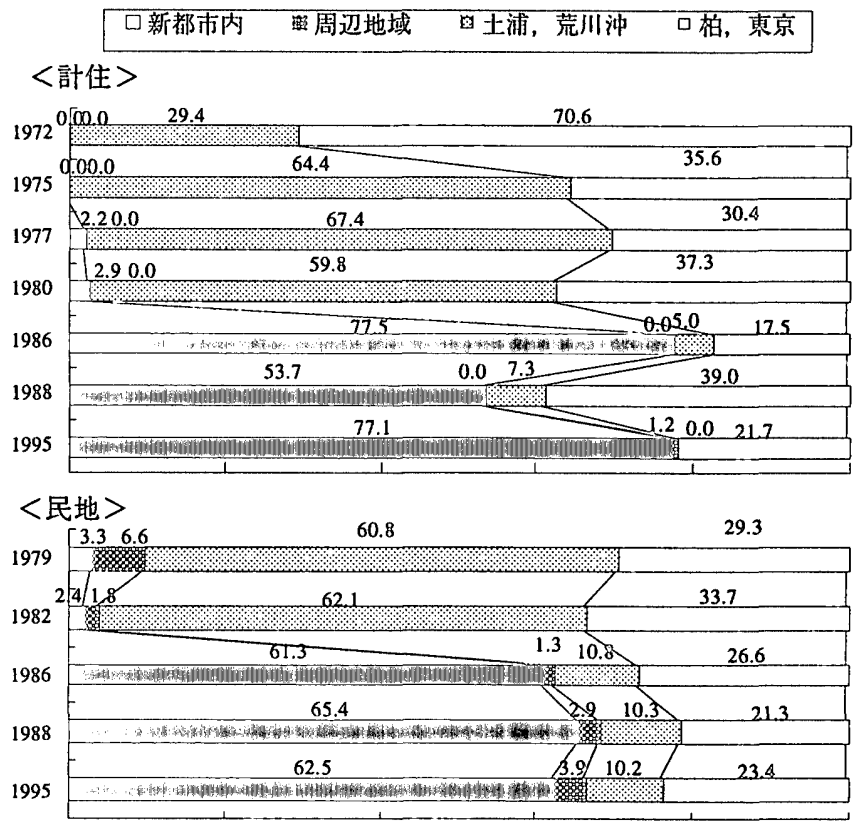

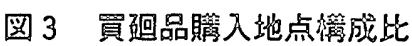


一方買迴品については、<計住 ><民地 >とも80年、82年と86年 の間に劇的な变化があり、86年には新都市内充足率が77\%、61\%と 過半を占めるようになり、その後はほぼ安定した状態にある。この 大きな変化は、1985年開催の万博に関連して整備された都心の成立 に起因することは明らかである。

\section{(2) 近隣交流}

居住者の近隣交流を表す指標として、新都市における知人人数 ${ }^{6)}$ について、人数階層別分布および平均知人人数を図 4 に示す。く計 住>は、75、77、80、86、88、95年の 6 時点、<民地 >は、82、86、 88、95年の 4 時点である。

＜計住>については1988年まで順調に知人数が増加し、研究学園 都市建設初期に社会問題となったような、新開発地に移住してきて 孤立感を味わう人の数は大幅に減少し、社会的環境が一応の安定状 態に達したことが分かる。

<民地＞の方は、初期の居住者が地縁性のある場合が多かった ため、始めから知人数の多い居住者の割合は大きかったが、同時に 知人なしの比率も高く、初期には 2 分されていたことが分かる。し かし、86年以降はく計住〉とほほ同じ状態になった。

1995年の調査結果からは、<計住 ><民地 >ともに知人人数の平 均值が減少したことが分かる。筑波研究学園都市における住民活動 に関する研究》によると、地域において協力して解決すべき問題が 減少した85年以降、住民活動の主題が地域の問題から全国的、広域 的課題へシフトしていった経緯が明らかにされているが、この近隣 における知人数の減少は、住民交流にしめる近隣の比重がやや軽く なったためとも解釈される。

\section{3.居住者意識について}

\section{（1）定住志向}

居住者と研究学園都市との結び付きの強弱を、居住継続の意思 によって捉えようしたのが定住志向であり、その変容を示したもの が図 5 である。（計住＞については72、75、77、80、86、88、95年 の 7 時点、<民地 >については、86、88、95年の 3 時点の比較であ る。

ここでは、「あなたは、筑波研究学園都市に住むことに対してど のようにお考えですか」という質問に対する回答を、肯定（事情が 許せば、ずっと住み続けたい+事情が許せば住み続けたい)、消極的 否定（どちらともいえない+あまり住み続けたいと思わない）、積極 的否定（事情が許せばすぐにでも移転したい）の3カテゴリーの比 率で示した。

＜計住＞はその殆どが給与住宅であり、持家住宅が中心となっ ているく民地>と同列には論じられないが、肯定的意識が72年の $24 \%$ から 95 年の $59 \%$ まで、徐々に上昇し、86年以降は $50 \%$ を回っ ている。

一方、<民地〉はその大部分が持ち家であることから、86、88年 には肯定が75\%以上と高く、積極的否定は、5\%以下であった。し かし、95年については肯定が72.5\%と多少の減少が見られる。この 理由としては $2 つ の$ 事柄が影響していると考えられる。まず第 1 は、<民地〉調査の対象者の内訳を見てみると、もともとこの地域 に長年居住し定住志向が高いと考えられる旧集落からの居住者が、 86 年約 $6 \% 、 88$ 年約 $10 \%$ の割合で含まれているのに対し、95年の調
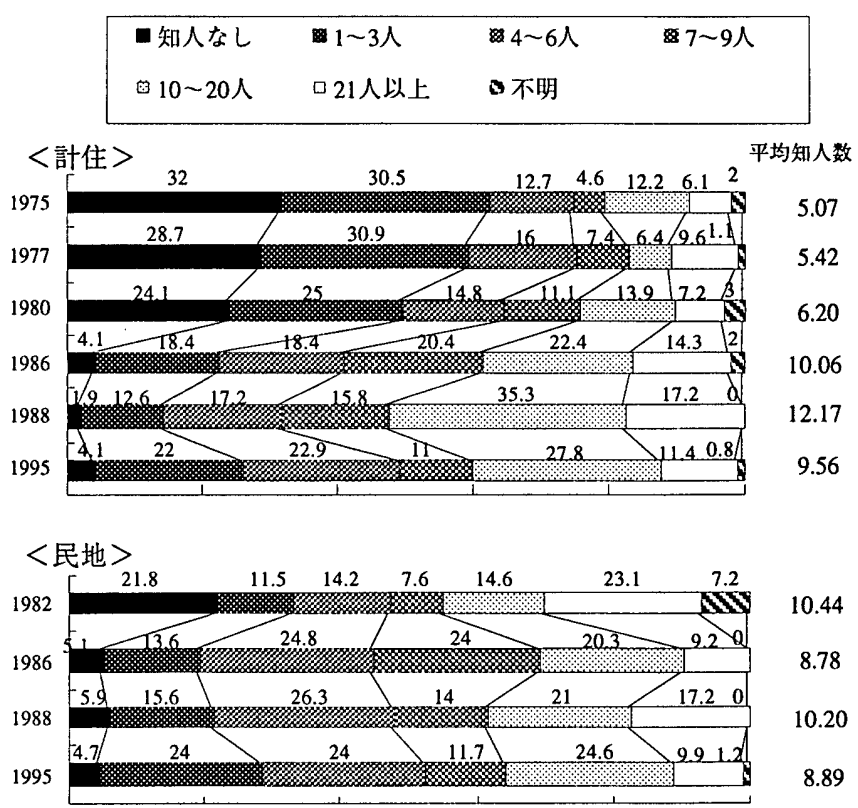

図 4 知人数階層構成比
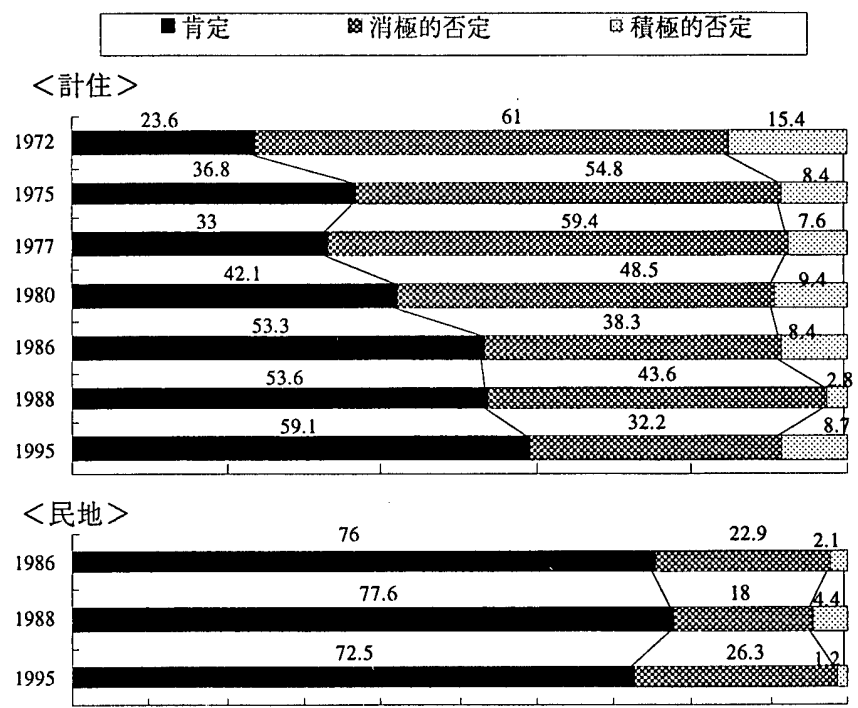

図 5 定住志向構成比

査においては民有地の市街化が進行したことに伴い、新規住民の母 集団が増加し、調査対象者をランダムサンプリングで抽出した結果、 旧集落の住民が全く含まれなくなったことが反映していること ${ }^{8)} 。$ 第 2 に元来、戸建て、持ち家住宅地区として建設傾向の高かったく 民地>において、近年集合住宅及び借家住宅の建設增加傾向が見ら れ、それらの居住者意識が影響を与えていると考えられることであ る9)。

いずれにせよ、このような高い定住肯定率に達したことは、新 都市が他地域からの来住者にとっても、定住環境として評価される だけの質的水準になっていることを示している。

\section{（2）居住環境評価}

居住者からみて、居住地である筑波研究学園都市がどのように 評価されてきたかを明らかにするために、総合的にみた居住環境評 価 (総合評価) と、個別項目毎の評価（個別評価）を、良い、やや 良い、どちらともいえない、やや悪い、悪いの 5 段階評価で答えて もらった。個別評価は、住宅の広さ快適さ（住宅）、日常の買い物 
等の便利さ（買物）、日常生活のための利便施設の状況（施設）、医 源施設サービス (医痖)、交通の便 (交通)、子弟の教育環境（教育）、 立化的楞境（文化）、近所との交友つき合い（交流）、自然環境（自 然）の 9 項目である。図6はく計住くについて、75、80、86、88、 95の 5 時点の、どちらともいえないの回答を除いた肯定的評価を左 側に、否定的評価を右側に示したものである。眓 7 は同じくく民 地>について、79、82、86、88、95の 5 時点の評価である。

まず、総合評価についてみると、く計住 ><民地 >ともに初期 の段階では否定的評価が高かったが、徐々に肯定的評価の割合が高 くなっている。特に、<計住〉の初期段階の变化度合いは顕著であ ク、80年には肯定が否定を上回り、86年には肯定 $65 \%$ 、否定 $8 \%$ と いう高い評価が得られている。しかし、95年には肯定60\%、否定 14\%と多少評価が下がりつつあることがうかがえる。これに対 し、〈民地>は86年の段階では肯定 $58 \%$ 、否定 $16 \%$ と（計住>に比 べて評価はやや低かったが、95年には肯定74\%、否定7\%と逆に極 めて高い評価となった。これらから、く民地〉に関しては、連続的 に居住愣境が良好とみなされるようになってきているということが いえる。

次に個別詽価についてだが、く計住>の（住宅）を除く8項目 全ての肯定的評価の割合が88年まではほは順調に増大してきていた のが、95年になって減少するという結果がでている。否定的評価に 関しても、割合の幅はあるが、(医療)、(文化) 以外の 7 項目につ いて増大している。特に、(交通)、(交流)はその割合が高い。ま た、(住宅)に関しては、肯定的評価が約50\%以上を維持し続けて いるのに对し、否定的評価は86年の段階で $35 \% 、 95$ 年の段階で、 $30 \%$ を占めていることから、当初好評だった公務員住宅の質が一般 の住宅水湦が向上したことにより、相対的に評価が下がってきたも のと捉えることができる。

これらの結果から、<計住＞に関しては、住民の要求度が増加 し、20年前に建設された住宅地がその要求に応えられていないこと がうかがえる。一方、<民地>の肯定的評価を95年と88年の 2 地点 で比較してみると、9 項目のうち（住宅)、(文化)、(交流) 以外の 6 項目が増加している。このうち (施設)、(教育) 以外の 4 項目に ついては、増加率が高くないことや、86年以前との比較から、安定 した状態と捉えられる。否定的評価は、(交通)以外は減少してお り、特に（買物）、(施設）は50\%以上減少していることから、民地 に封するこれらの施設が充実してきていることが示されている。

95年の段階で、肯定的評価が否定的評価を上回っていないもの はく計住〉く民地〉共に（交通）ただ 1 項目である。このことから、 新部市にお仢る交通の問題は20年を経た現在も未だ解決されておら ず、今後の計画において考應すべき最大の問題であると考えられる。 全体として、86年以前に生じていたく計住〉とく民地〉の評価格差 低、88年を境に解消し、95年にはむしろく民地〉の方が評価が高く なってきている。

これらから研究学園地区の居住環境は全体にわたってある一定 の成熟度に逵したと捉えることができると同時に、市街化が淮行し ているく民地＞が、計画的に整備されたく計住＞の評価を越える段 階に達したことは注目に值する。

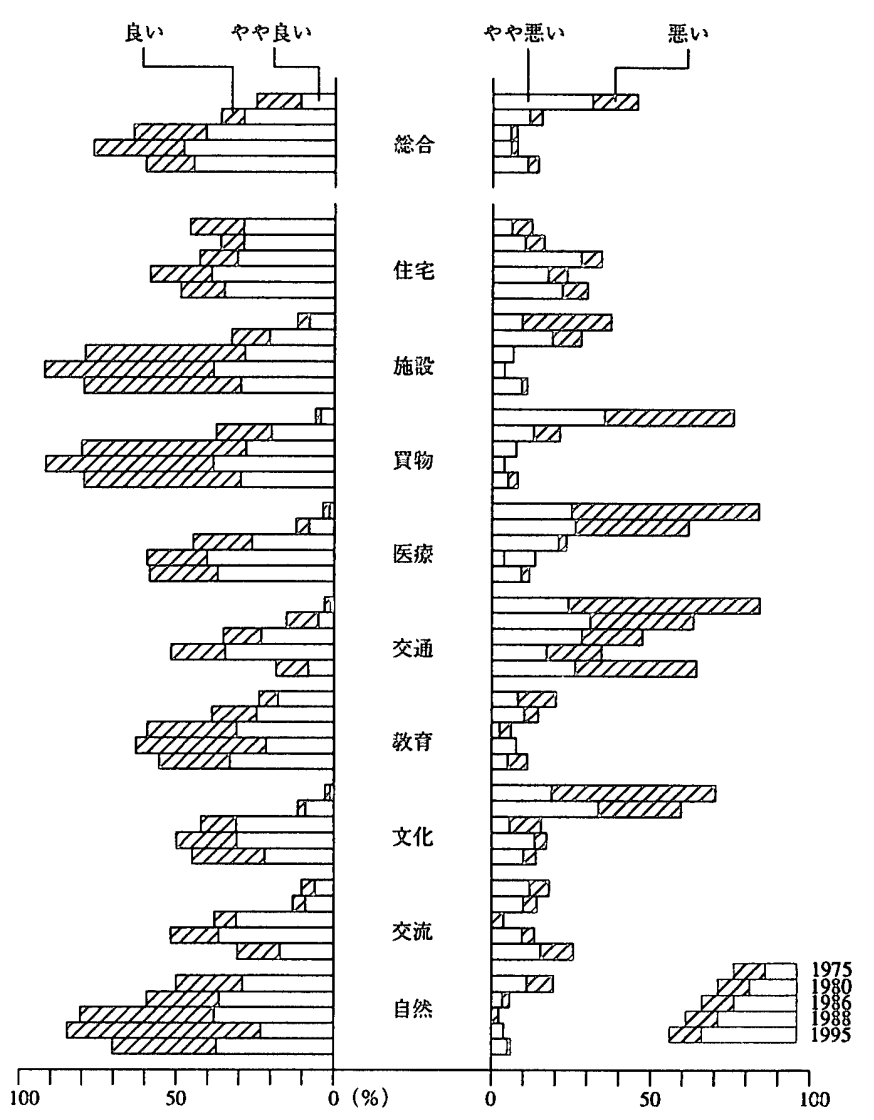

圆 6 扂住環境評価＼cjkstart訫住＞

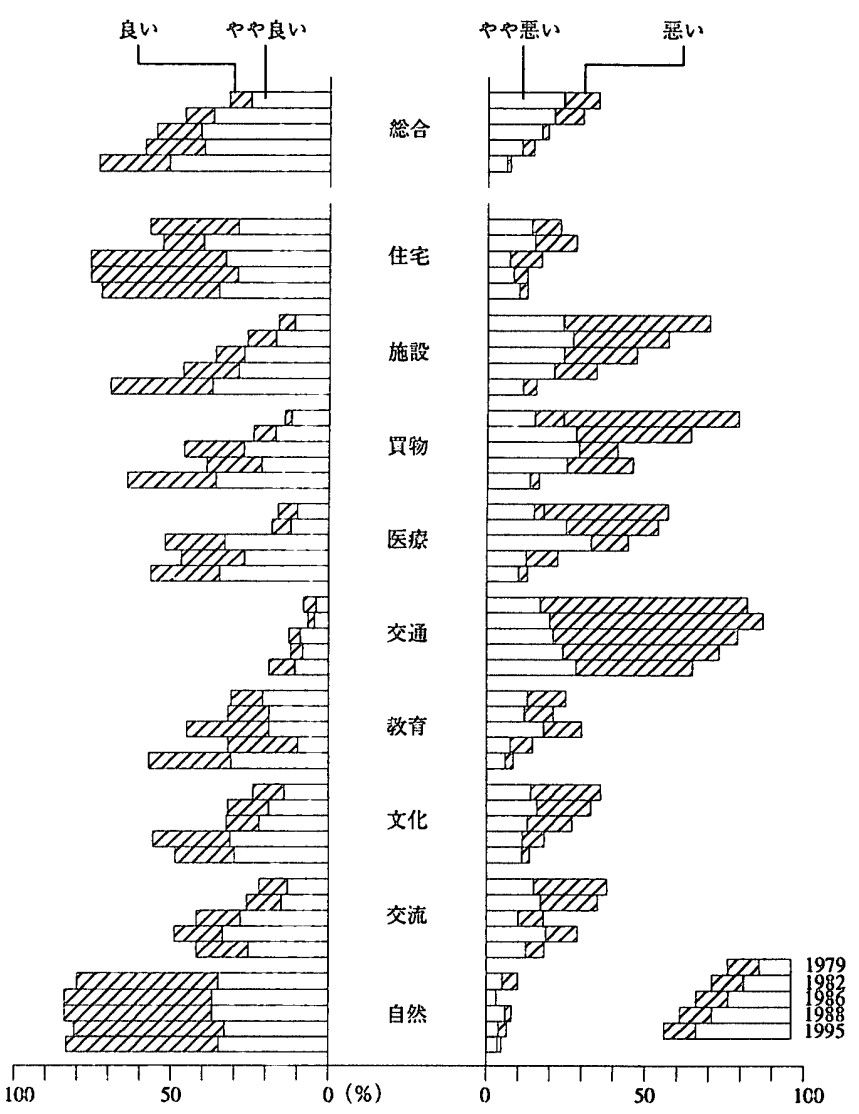

图 7 居住環境評価＜民绝＞ 
4 居住者の生活行動及び意識の变容過程の特性について

（1）生活行動及び意識の変容パターン

ここでは、これまで検討してきた居住者の生活行動、意識の各 側面の相互関係を23年間の時系列変化のパターンに注目して考察を 加える。

図 8は、これらの各項目についてプラス側を示す回答10 の比率 （知人人数は平均人数）を重ね合わせて示したものである。この図 から、大きく2タイプの変容傾向が読みとれる。まず第 1 は、1980 から86年にかけて平均知人人数（<民地〉）を除く全ての項目が大 幅な上向きの変化を示すことである。この上向き変容を示す理由と しては、80年が学園都市概成の年で、国立研究機関の移転の完 了、<計住>への人口定着終了の年であることから、この新都市が 未熟なりにも多様性を持つ都市として機能し始めた時期であるこ と。また、 85 年の科学万博開催に伴う都市整備の進行及びクレオ （西武百貨店とジャスコ）がオープンし商業サービスが充実したこ とによるものであると考えられる。

第 2 は、88 95年間のいくつかの項目の落ち込みないし停滞であ

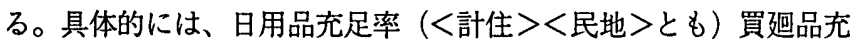
足率 $<$ 民地 $>$ 平均知人人数（<計住 $><$ 民地 $>$ とも）定住肯定率 $<$ 民地 >居住環境評価＜計住 $>の 7$ 項目が減少しており、上昇したの は買䞟品充足率＜計住＞定住志向肯定率＜計住＞居住環境評洒＜民 地>の 3 指標のみである。この理由として考えられるのは、近年新 都市周辺部の開発が進行し、この状況を受けて居住者の生活行動範 囲が広域化することに伴なって、相対的に新都市内での充足行動が 減少し、それにつれて都市内環境への意識が弱くなってきたことが 考えられる。

次に、生活行動と意識の相互関係について読みとっていく。ま ず、生活行動を示す充足率の值は80 85年間に70 90\%というかな り高い数值に達するのに対し、意識は $80 〜 82$ 年間は $50 \%$ 以下で、 86 年時点でも 55 $85 \%$ と行動指標より変化の時期が遅く、またその值 も低いことがわかる。このことから、生活行動の変容は環境の変化 に敏感に反応するのに対し、意識の変化はより緩やかであり、その 結果両者の間には時間的なズレと到達率に差が生じることが明らか になった。

しかし、このパターン図からは定性的な方法でしか行動及び意 識の変容過程を論ずることができない。そこで、次にこの生活行動 と意識の構造的な関係を明らかにすることを試みると同時に、意識 と現実の空間変容との関係についても同様の分析を行う。

（2）定住志向の規定要因について

ここでは、居住者意識を代表する指標としてく計住＞の定住志 向を取り上げ、これと生活行動及び都市空間の整備変容の 2 つの事 柄についての構造的関係を明らかにすることを試みる。なお、生活 行動を表す指標としては、日用品充足率く計住＞、買い迴り品充足 率く計住〉、知人人数く計住〉を使用する。また、都市空間の整備 状況を示す指標としては、四 9 に示す総人口、民有地市街化面積率、 民有地の非居住施設総数、公的サービス施設数のそれぞれの年あた りの增堿度を指標とする"1。

定住肯定率を目的変数、生活行動及び空間に関する変数群を説 明変数としてそれぞれについて重回帰分析を行った。結果を表 2 に 示す。

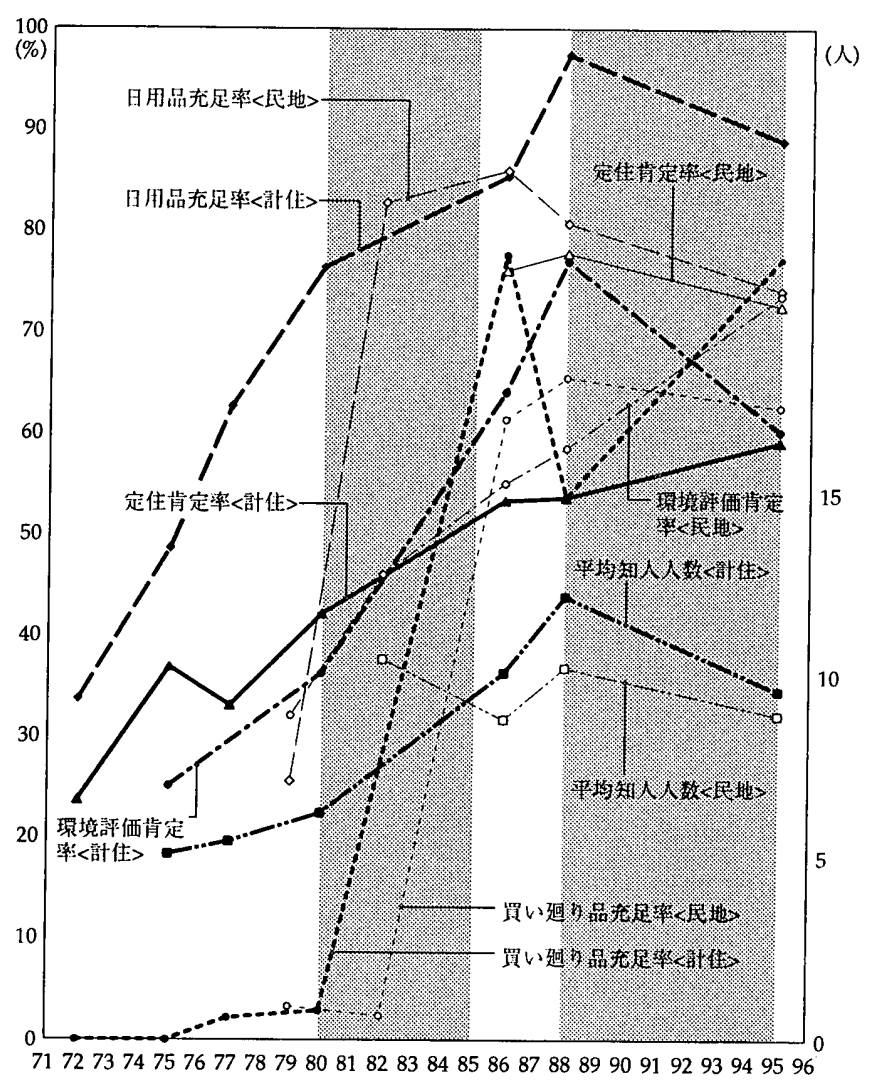

図 8 生活行動・意識の变動パターン図

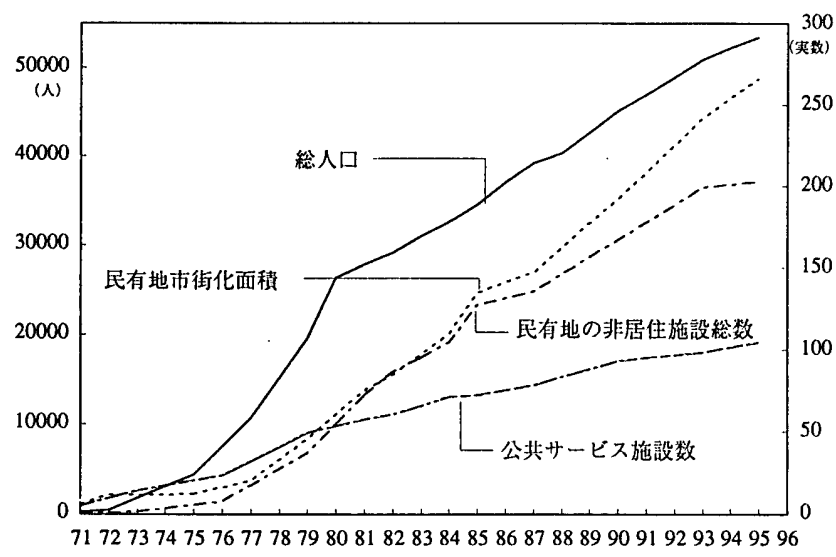

図 9 空間整備変動パターン図

表 2 重回帰分析結果

\begin{tabular}{|c|c|c|c|c|}
\hline \multirow{5}{*}{ 生活行動 } & & $\begin{array}{c}\text { 決定係数 } \\
\text { F値 }\end{array}$ & $\begin{array}{r}0.893 \\
17.620 \\
\end{array}$ & * \\
\hline & 項目名 & 標準回帰係数 & T值 & \\
\hline & 日用品充足率 & 0.631 & 2.552 & $\Delta$ \\
\hline & 買い廻り品充足率 & 0.442 & 1.481 & \\
\hline & 平均知人人数 & 0.061 & 0.346 & \\
\hline \multirow{7}{*}{ 空間整備 } & & 決定係数 & 0.415 & \\
\hline & & F値 & 5.261 & ** \\
\hline & 項目名 & 標準回帰係数 & T值 & \\
\hline & 民有地市街化面積率増減度 & 0.800 & 3.121 & ** \\
\hline & 総人口増減度 & 0.120 & 0.626 & \\
\hline & 民有地非居住施設数増減度 & -0.308 & -1.135 & \\
\hline & 公的サービス施設数増減度 & -0.286 & -1.632 & \\
\hline
\end{tabular}


まず、生活行動の中で、定住肯定率に影響を与えているものは、 標準回帰係敨が 0.631 の日用品充足率である。つまり、日常生活の利 便性が増せば定住志向が高まると捉えることができる。

次に、定住肯定率と都市空間の整㣁状況との関係であるが、こ れは民有地市街化面積率増加度の標準回帰係数が 0.800 となることか ら、この指標が定住肯定を促進することに圧倒的な影響力を持って いることが読みとれる。この新都市においては、計画的市街地はす でに計画に沿った建設がほぼ完了しており、現状における都市化の 進展を端的に表現するのは民有地における建設活動の状態である。 このことを考えると、都市化の進展が定住意識を高めることに大き く寄与していることがわかる。

これらのそれぞれの分析結果を照らし合わせ、意識と生活行動 及び空間整㣁との関係を大まかに捉えると、居住者の定住意識を高 めること、すなわち新都市との結びつきを強めるための条件として、 日常生活の利便性の確保と都市としての立実があげられる。前者は 現状における安心感を、後者は将来に向けての期待感を示す要因と 考えられよう。

\section{5 まと的}

これまでの分析、考察から本調査における考察は以下の 4 点に まとめられる。

1）86年頃までズレを生じていた新都市におけるく計住 $>$ と民 地>の格差は、生活行動、居住環境評価等の結果からその差はほと んどなくなり、定住については、く民地〉の方が持ち家の比率が高 いことから肯定者の割合が多い。

2）88年調㚗から95年調査にかけて、いくつかの項目で下降ないし 停滯が見られ、それまで一貫して上昇してきた行動の充足状況、意 識の肯定傾向に変化が生じていることが分かった。この傾向は、新 都市の形成が一段落し、次の段階に入りつつある兆しとも考えられ、 今後さらに慎重に確認する必要があろう。

3 ）生活行動と意識の変容パターンの分析から、両者の関係はまず 生活行動が変化し、遅れて意識が変化すると共に前者の変化がダイ ナミックであるのに対して後者のそれは緩やかであることがわかっ た。

4) 定住志向を代表指標として意識と生活行動及び空間整備との関 係性を捉えるために重回帰分析をそれぞれ行った結果、日用品充足 率と民有地市街化面積率との結びつきが明らかになった。

全体を通しては、これらの生活及び意識調査から研究学園地区 のく計住〉、〈民地〉共に一定の成熟度に既に達しており、最近で は、居住者の生活行動圈が拡大すると共に、より高度な都市の環境 整備及び機能の充実を求める傾向がでてきている。また、意識と生 活行動及び空間構造との結びつきが確認できたことにより、この成 果を他の新都市の整備方向に関して部分的にではあるが適用できる 結果を導き出すことができたと考える。

謝辞

本研究のアンケート調査を担当した多くの大学院生及び調査に 協力して下さった新都市の居住者の皆さんに感謝致します。
$<$ 注 $>$

1) 文 1)

2）研究学園都市における居住者意識の解析については上笹、菱山 らによる文 5）等の研究があるが、これらは意識のみの研究であ り空間整備データと照合された研究ではない。

3）この 4 項目以外に愛着度、まちづくり意識なども時系列的にデ 一夕を収集しているが時点数が少ないため、本報では省略する。

4) 国立研究機関の移転が終了した1980年3月を「概成」と呼ぶ。

5 ）周辺地域に立地している大型店舗の建設時期別の数は、1979年 以前：1、80 84年：1、85～89年：1、90年以降：6となってお り、最近の建設量が多い。

6) アンケートでは、「近所で顔・名前を知っていて、会えば世間 話をする程度の友人」との交流について質問している。

7) 文 4)

8) 文 5)にも、旧集落に居住する住民の方が、定住志向が高いこ とが報告されている。

9）近年の<民地>における集合住宅の建設の増加は文 6）等に報 告を行っている。

10）生活行動に関する指標は全体に対する新都市内の充足率、定住 志向及び居住環境評価は全体に対する肯定率の割合をプラス側の 比率として使用した。

11）この抽出方法は、文7）に示されたデー夕に最新のものをつけ 加えた上で、変動値を年率に計算し直し、その值を增減度とした。

<立賠 $>$

1) 土肥博至、若林時郎：筑波研究学園都市における住民の生活と 意識の変容について、日本都市計画学会学術研究論文焦、No.23, p $337 \sim 342,1988$

2) 桑原盾：筑波研究学園都市における住民意識と居住環境評価、 筑波大学環境科学研究科修士論文、1989

3) 土肥博至、福本佳世他：筑波研究学園都市における居住者の行 動と意識にの変容について、筑波の環境研究、No.16,p $25-37$, 1997

4) 土肥博至、畠瀬和志：筑波研究学園都市における住民活動につ いて、筑波の環境研究、No.14,p $17 \sim 28,1992$

5）上笹恒、菱山謙二：筑波研究学園都市における住民意識構造の 解析、筑波の環境研究、No.11,p $33 \sim 42,1988$

6）土肥博至、坂本淳二他：筑波研究学園都市における民有地の市 街化に関する研究 9 （1995年までの状況）、その 1 〜 その 3 1995 年度日本建築学会関東支部研究報告集、p 237 284, 1996

7 ) 河津玲、土肥博至他：筑波研究学園都市の都市形成過程に関す 万研究 4、日本建築学会学術講演梗概集、p 439 440, 1994.4

（1997年 2 月 10 日原稿受理，1997年 7 月 4 日採用決定） 